\title{
IDENTIFICATION OF RISK POTENTIALS OF DEGENERATIVE DISEASES AMONG THE COASTAL COMMUNITY IN JEMBER AND BANYUWANGI DISTRICT, EAST JAVA PROVINCE
}

\author{
Noveyani AE*, Artharini OM, Sari LD, Munfarisa A, Wahyuni YT \\ and Sari YP
}

Department Epidemiology, Public Health Faculty, Universitas Jember, Indonesia

\begin{abstract}
Degenerative disease is a disease caused by tissue/organ deteriorates and loses its functional ability. Coastal community mostly worked as fishermen and fishmonger, that rely heavily on physical strength because of the high workload of outdoor activities. These activities may lead to premature degenerative disease. The purpose of this cross-sectional study was to explore the potential risks of degenerative diseases among the coastal community. The survey was carried out from Jember and Banyuwangi District, Indonesia during May-June 2021 on the population of the coastal community. We used cluster random sampling as a sampling technique, resulted 194 respondents. Then it was analyzed descriptively. The results stated that the respondents were on reproductive age and most of them did not have a family history of degenerative diseases. For risk potentials: BMI of $46.9 \%$ respondents was normal (18.5-22.9). 87.3\% of them had a smoking habit with 10-19 cigarette sticks/day. Majority (40.2\%) started smoking at 15-18 years old. Most of them (83\%) also were exposed to cigarette smoke. More than half (57.2\%) routinely did strenuous activity. Most of them (60.8\%) work outside with average sun exposure of $>5$ hours/day. Most of them consumed seafood (70.1\%) and vegetable (60.3\%) as daily intake. However, mostly never restricted salt intake for their food/cooking (49.4\%) and sometimes still consumed fatty food $(59.2 \%)$ and meat fat $(88.1 \%)$. Therefore, their strenuous physical activity, excessive sun exposure, and unhealthy lifestyle can cause degenerative of the organ and tissue that could lead to premature degenerative diseases. This degenerative process if not immediately prevented, it can reduce productivity and have an impact on decreasing fishermen's income.
\end{abstract}

Keywords: degenerative, fisherman, coastal, risk potential, community

\section{Introduction}

Degenerative diseases are chronic non-communicable diseases that arise due to the declining condition and function of body organs along with the aging process (Handajani et al., 2012). These diseases include cataracts, diabetes mellitus, obesity, osteoporosis, rheumatoid arthritis, cancer, and cardiovascular diseases such as coronary heart disease and stroke. Based on the results of Riskesdas in 2018, the prevalence of non-communicable diseases has increased when compared to Riskesdas 2013(Kemenkes RI, 2019). Report from the Jember District Health Office stated that there were six of the ten most degenerative diseases affected the elderly, those were osteoporosis, hypertension, diabetes, rheumatoid arthritis, gouty arthritis, and cataracts. Degenerative diseases can be caused by two risk 
factors, namely modifiable and non-modifiable risk factors. Factors that cannot be changed include gender, age, and genetics. While the risk factors that can be changed include smoking habits, occupation, physical activity, alcohol consumption, BMI, and waist circumference or obesity (Amila, Evarina Sembiring, 2021).

East Java is surrounded by coastal areas. Banyuwangi and Jember regency are southern coastal areas, specifically the area of Muncar Fishingport (Banyuwangi) area and Puger Fishingport (Jember). In this area only certain parts that can be developed as fishing settlements and tourism areas. So, by examining the health conditions of the coastal communities there, it is expected to prevent potential risks that could affect their health and productivity. Also this can maintain and ensure the availability of productive human resources before this area becomes more busy area such as the northern coast of East Java.

The livelihood of coastal community are mostly fishermen and fishmongers. According to data from the Kedungrejo Village Government, Muncar District, Banyuwangi in 2020, the majority of the population's livelihood is in the fishery sector. Where 154 of them work as fishermen, 3,541 people as fishery business workers, and 5,112 people as fishery business owners. While in Puger District, Jember the number of fishermen were 10,676 and fishermen's households were 2,325 (Central Bureau of Statistics of Jember, 2020) .. These jobs are strenuous activities that rely heavily on physical adequate condition. In addition, most of their activities are outdoor. Daily strenuous activities and excessive sun exposure are risk factors for degenerative diseases. Previous research showed that there were eating habits of coastal communities in the Soropia Primary Health Center, Konawe Regency who like to eat foods that contained high cholesterol, and were high in salt intake as preservatives (Musdalifah et al., 2020). This activity could increase the risk of hypertension, where hypertension is one of the main risk factors for various degenerative diseases. Based on preliminary study in District Health Office of Jember, there was increasing of hypertension among fisheries in Puger subdistrict from 1656 in 2018 to 2081 in 2019 . We suspected that there are specific lifestyle related to coastal community that contribute to degenerative diseases. Moreover, degenerative diseases have a high mortality rate and can decline a person's productivity (Hanum \& Ardiansyah, 2018). Therefore, authors aimed to identify the potential risks for degenerative diseases in coastal community.

\section{Materials and Methods}

This was a cross-sectional study. The survey was carried out from Jember (Subdistrict of Puger) and Banyuwangi District (Subdistrict of Muncar), East Jawa Province, Indonesia during May-June 2021 on the population of the coastal community. We used cluster random sampling as a sampling technique, resulted 194 respondents (106 from Muncar and 88 from Puger). The variable was BMI, smoking behavior, family history of degenerative diseases, daily consumption, physical activity, and duration of sun exposure. Then it was analyzed descriptively. The survey conducted through direct interview using Google form (we highly adhered the health protocol regarding to covid-19 pandemic). The study was approved by the Health Research Ethics Committee, Faculty of Public Health, Universitas Jember, No. (ethics certificate Number 57/KEPK/FKM-UNEJ/VI/2021). 


\section{Results}

\section{Characteristics}

Table 1: Characteristics of Respondents $(N=194)$

\begin{tabular}{|c|c|}
\hline Characteristics & $\mathrm{n}(\%)$ \\
\hline \multicolumn{2}{|l|}{ Gender } \\
\hline Male & $116(59.8)$ \\
\hline Female & $78(40.2)$ \\
\hline \multicolumn{2}{|l|}{ Academic Background } \\
\hline No Formal School & $12(6.2)$ \\
\hline Elementary School & $117(71.3)$ \\
\hline High School & $49(25.3)$ \\
\hline College & $16(8.2)$ \\
\hline \multicolumn{2}{|l|}{ Occupation } \\
\hline Fisherman & $86(44.3)$ \\
\hline Fishmonger & $67(34.5)$ \\
\hline self-employed & $19(9.7)$ \\
\hline Private sector employee & $11(5.7)$ \\
\hline Teacher & $5(2.6)$ \\
\hline Farmer & $1(0.5)$ \\
\hline \multicolumn{2}{|l|}{ Secondary Occupation } \\
\hline Yes & $32(16.5)$ \\
\hline No & $162(83.5)$ \\
\hline \multicolumn{2}{|l|}{ Workplace } \\
\hline Indoor & $76(39.2)$ \\
\hline Outdoor & $118(60.8)$ \\
\hline \multicolumn{2}{|l|}{ Monthly Income (IDR) } \\
\hline$<1000.000$ & $59(30.4)$ \\
\hline $1.000 .000-2.500 .000$ & $99(51)$ \\
\hline$>2.500 .000$ & $36(18.6)$ \\
\hline
\end{tabular}

Age of respondents was between 21-62 years old (productive age) and most of them (59.8\%) were male (table 1). Majority worked as fishermen (44.3\%) and fishmonger (34.5\%) and worked outdoor (60.8\%). Most of them (83.5\%) only had single job. From $16.5 \%$ respondents that had side hustle, mostly that was self-employed. 


\section{Risk Factor}

BMI (Body Mass Index)

Table 2: $\quad$ BMI of Respondents $(N=194)$

\begin{tabular}{ll}
\hline BMI & $\mathrm{n}(\%)$ \\
\hline Underweight & $1(4.1)$ \\
\hline Normal & $91(46.9)$ \\
\hline Overweight & $43(22.2)$ \\
\hline Obesity & $52(26.8)$ \\
\hline
\end{tabular}

\section{Duration of Sun Exposure}

Table 3: Duration of Sun Exposure among Coastal Community $(N=194)$

\begin{tabular}{ll}
\hline Duration of sun exposure (hour/day) & $\mathrm{n}(\%)$ \\
\hline Low $(0-2)$ & $39(20.1)$ \\
\hline Moderate (3-5) & $55(28.4)$ \\
\hline High & $86(44.3)$ \\
\hline High $(6-7)$ & $33(38.4)$ \\
\hline Very high $(8-10)$ & $48(55.8)$ \\
\hline Extremely high $(\geq 11)$ & $5(5.8)$ \\
\hline
\end{tabular}

Since most of them worked outdoor that highly (44.3\%) exposed by the sun. Majority respondents got very high sun exposure $(44.3 \%)$ (table 3$)$.

\section{Smoking Behaviour}

Table 4: $\quad$ Smoking History and Cigarette Smoke Exposure of The Coastal Comunity (N=194)

\begin{tabular}{ll}
\hline Smoking History & $\mathrm{n}(\%)$ \\
\hline Never & $92(47.4)$ \\
\hline Ever & $102(52.6)$ \\
\hline Cigarette smoke exposed & \\
\hline Yes & $161(83)$ \\
\hline No & $33(17)$ \\
\hline
\end{tabular}


Table 5: Smoking Behaviour of The Coastal Comunity (N=102)

\begin{tabular}{ll}
\hline Smoking Behavior & $\mathrm{n}(\%)$ \\
\hline Current smoking status & \\
\hline Continue & $89(87.3)$ \\
\hline Stop & $13(12.7)$ \\
\hline First time smoking & $14(13.7)$ \\
\hline $10-14$ & $41(40.2)$ \\
\hline $15-18$ & $23(22.5)$ \\
\hline$\geq 19$ & $24(23.5)$ \\
\hline Forget & \\
\hline Smoking Duration & $19(18.6)$ \\
\hline $1-15$ & $26(25.5)$ \\
\hline $16-30$ & $23(22.5)$ \\
\hline $31-50$ & $12(11.8)$ \\
\hline Forget & $36(35.3)$ \\
\hline Smoking intensity (stick/day) & $39(38.2)$ \\
\hline$\leq 9$ & $27(26.5)$ \\
\hline $10-19$ & \\
\hline$\geq 20$ & $99(97.1)$ \\
\hline Knowledge of the harmful of cigarette & $3(2.9)$ \\
\hline Know &
\end{tabular}

More than a half of respondents have ever smoked (52.6\%) (table 4) and majority (83\%) exposed by cigarette smoke (table 4). From those who have ever smoked, $87.3 \%$ continued smoking till now eventhough almost all (97.1\%) stated that they have already known the harmful of smoking (table 5). The average first time of smoking was 18 years old. So, the average duration of smoking was 41 years. Most of them (38.2\%) smoked 11-20 sticks/day.

\section{Lifestyle}

Table 6: Lifestyle of The Coastal Community $(N=194)$

\begin{tabular}{lll}
\hline Lifestyle & $\begin{array}{l}\text { Yes } \\
\mathrm{n}(\%)\end{array}$ & $\begin{array}{l}\text { No. } \\
\mathrm{n}(\%)\end{array}$ \\
\hline Physical activity & & \\
\hline Light & $179(92.3)$ & $15(7.7)$ \\
\hline Moderate & $156(80.4)$ & $38(19.6)$ \\
\hline Vigorous & $111(57.2)$ & $83(42.8)$ \\
\hline Exercise & $87(44.8)$ & $107(55.2)$ \\
\hline
\end{tabular}




\begin{tabular}{cll}
\hline Health Check up & & \\
\hline Blood Glucose & $121(62.4)$ & $72(37.1)$ \\
\hline Blood Pressure & $176(90.7)$ & $18(9.3)$ \\
\hline
\end{tabular}

Table 7: Daily Consumption of The Coastal Community $(N=194)$

\begin{tabular}{lllll}
\hline Daily Consumption & $\begin{array}{l}\text { Always } \\
\mathrm{n}(\%)\end{array}$ & $\begin{array}{l}\text { Frequently } \\
\mathrm{n}(\%)\end{array}$ & $\begin{array}{l}\text { Sometimes } \\
\mathrm{n}(\%)\end{array}$ & $\begin{array}{l}\text { Never } \\
\mathrm{n}(\%)\end{array}$ \\
\hline Salt intake restriction & $15(7.7)$ & $33(17)$ & $40(20.6)$ & $96(49.5)$ \\
\hline Alcohol & $2(1)$ & $41(21.1)$ & $36(18.6)$ & $113(58.3)$ \\
\hline Seafood & $136(70.1)$ & $58(29.9)$ & 0 & 0 \\
\hline Coffee & $26(13.4)$ & $13(6.7)$ & $43(22.2)$ & $112(57.7)$ \\
\hline Red Meat & $7(3.6)$ & $54(27.8)$ & $114(58.8)$ & $19(9.8)$ \\
\hline Meat Fat & 0 & $23(11.9)$ & $171(88.1)$ & 0 \\
\hline Fatty food (gorengan, lodeh etc) & $9(4.7)$ & $31(16)$ & $115(59.2)$ & $39(20.1)$ \\
\hline Vegetable \& Fruit & $44(22.7)$ & $90(46.4)$ & $58(29.9)$ & $2(1)$ \\
\hline
\end{tabular}

Family History of Diseases

Table 8: Family History of Degenerative Diseases among Coastal Community $(N=194)$

\begin{tabular}{lll}
\hline Type of Diseases & $\begin{array}{l}\text { Yes } \\
\mathrm{n}(\%)\end{array}$ & $\begin{array}{l}\text { No } \\
\mathrm{n}(\%)\end{array}$ \\
\hline Cataract & $20(10.3)$ & $174(89.7)$ \\
\hline Diabetes Mellitus & $47(24.2)$ & $146(75.8)$ \\
\hline Arthritis Rheumatoid & $35(18)$ & $159(82)$ \\
\hline Hypertension & $41(21.1)$ & $153(78.9)$ \\
\hline Coronary artery disease & $16(8.2)$ & $178(91.8)$ \\
\hline Stroke & $28(14.4)$ & $166(85.6)$ \\
\hline
\end{tabular}

Most of respondents were physically active (table 6). Moreover, most of them also always consumed seafood $(70.1 \%)$ and frequently consumed vegetable and fruit (46.4\%) for daily consumption. However, the majority never restricted salt intake for their food/cooking (49.4\%) and sometimes still consumed fatty food (59.2\%) and meat fat (88.1) (table 7). Although mostly ever checked their blood glucose and blood pressure, however they did not routinely check up. Table 8 shows that most respondents did not have degenerative diseases from family history.

\section{Discussion}

They were in productive age, the BMI status was normal, and did not have family history of diseases. For those reason, non-modifiable risk factors of degenerative disease is not the potential risks for coastal 
community. However, the potential risks came from modifiable risk factor, those are working outdoor with excessive sun exposure, smoking behaviour, cigarette smoke exposure, daily strenuous activity, unrestricted salt intake, and fatty food consumption.

Based on Indonesian skin type, UV radiation for Indonesian leads to sunburn after more than 60 minutes (Institute for Quality and Efficiency in Health Care, 2018). The sun's UV rays are the strongest between 10 a.m. and 4 p.m, moreover WHO highly recommend to limit exposure to the sun during these hours (WHO, 2003). Previous study stated that overexposure of ultraviolet radiation can cause Basal Cell Carcinoma (BCC) (Neale et al., 2007). BCC is the most common of all skin cancers. Acute intense exposures sufficient to cause sunburn among people whose ability to tan makes the skin generally less susceptible to the carcinogenic effects of ultraviolet radiation. From the epidemiology perspective, there were indirect and direct evidence that sun exposure causes skin cancer. Indirect evidences were incidence of skin cancer in populations generally increases for those who live near the equator; The highest densities of each kind of skin cancer are on body sites that are usually exposed to the sun when outdoors and all skin cancers are rare on sites that are rarely exposed to the sun, so it was positively associated with outdoor occupation. Meanwhile the direct evidence was from some epidemiological studies, First, from cohort study recorded newly incident skin cancers, from comparison incidence of skin cancer at different levels of sun exposure of individuals in the group. Second, from case-control study, people with newly diagnosed skin cancer have been asked to recall their sun exposure, resulted an estimate of risk of skin cancer in relation to different levels of sun exposure. Third, biological studies in humans have shown direct links between solar UV radiation and some skin cancers. Fourth, subjects have been randomly allocated to receive or not receive special interventions aimed at reducing sun exposure and subsequent risk of skin cancer (Armstrong et al., 2004). Melanoma also occurs at relatively young ages, and given the importance of early life exposure to sunlight, prevention campaigns that are directed towards the young might be more cost effective (Armstrong et al., 2004).

Based on the category of smoker, that is light (1-9 cigarettes per day), moderate (10-19), and heavy smokers (>19) (Lohse et al., 2016), the coastal community was moderate smoker. However they were smoking since adolescence, mostly since age 15-18 years old, and that was younger than the average of first time smoking nationally (Indonesian Ministry of Health, 2016). It could cause significant health problems for the future, including an increase of degenartive process of respiratory organs, increase severity of respiratory illnesses, decreased physical fitness and potential effects on lung growth and function (American Lung Association, 2020). Most importantly, an addiction to smoking often lasting when they had tried their first cigarette by the time they were 18 years old (The American Lung Association Epidemiology and Statistics, 2014). Moreover, previous study stated that number of cigarettes consumed is correlated with duration of smoking (Sundari et al., 2015). So the longer he smokes, the more cigarettes he smokes. Regarding degenerative diseases, previous study stated that cigarette smoking each are significantly associated with an increased diagnosis of lumbar degenerative disc disease (An et al., 1994; Jakoi et al., 2017). Previous studies also have analyzed the link between lower back pain and smoking (An et al., 1994; Battié et al., 1991; Mattila et al., 2008). The primary mechanism involves malnutrition of the disc caused primarily by tobacco-related anoxia and vascular disease. Malnutrition of the disc has previously been shown to be strongly associated with disc degeneration (Livshits et al., 2001; Mattila et al., 2008) and vascular disruption of this nutritional supply is a key role (Boubriak et al., 2013; Iwahashi et al., 2002; Liu et al., 2009). The increased blood concentration of carbon monoxide in smokers results in a decreased oxygen-carrying capacity of hemoglobin and this likely represents a further insult to the intervertebral disc's nutritional pathway 
(Jarvis et al., 1987; Rietbrock et al., 1992). Cigarettes smoke may directly affect cell viability and activity in the intervertebral disc (Akmal et al., 2004; Fogelholm \& Alho, 2001). Gross examination of intervertebral disc tissue exposed to cigarette smoke demonstrates necrosis and fibrosis involving the nucleus pulpous and alteration in the layered composition of the annulus fibrosis (Iwahashi et al., 2002). The authors concluded that, with regards to male subjects, daily smoking was the strongest risk factor for degenerative disease, especially lumbar degenerative disc disease.

Since most of the coastal community did strenous activity every day, it can contribute to the increase of degerative organs. As stated by Leboeuf-Yde et al. that evaluated the association of self-reported physical hard labor, smoking and obesity in four hundred and twelve 40-year old Danes with MRI findings, back pain and a vertebral inflammatory process. They found that hard physical labor in combination with either heavy smoking or obesity was strongly associated with a vertebral inflammatory process (Leboeuf-yde et al., 2008).

Most of the respondents did not limit the salt intake. Whereas, WHO has suggested an upper limit of 1.7 grams of sodium per day (5 grams of salt per day) (Strazzullo et al., 2009; World Health Organization, 2006). Because high salt intake is associated with significantly increased risk of stroke and total cardiovascular disease (F. J. He \& MacGregor, 2009; Scientific Advisory Committee on Nutrition, 2003; Strazzullo et al., 2009). Based on the effects of high salt intake on blood pressure and on the prominent role of high blood pressure in promoting cardiovascular diseases (World Health Organization, 2006). Moreover, fatty food certainly contain trans fat, and cholesterol that can increase risk of cardiovascular diseases, diabetes mellitus type 2, and cancer (Sun et al., 2019). Based on metaanalysis by Strazullo (2009), support for the role of reduction in salt intake for the prevention of cardiovascular disease should be continue and strengthen (Strazzullo et al., 2009). The results of a metaanalysis of randomised controlled trials of salt reduction, it was estimated that a reduction in habitual dietary salt intake of $6 \mathrm{~g}$ a day would be associated with reductions in systolic/diastolic blood pressure of 7/4 $\mathrm{mm} \mathrm{Hg}$ in people with hypertension and $4 / 2 \mathrm{~mm} \mathrm{Hg}$ in those without hypertension (F. J. He \& MacGregor, 2002). At the population level these reductions in blood pressure could predict an average lower rate of 24\% for stroke and 18\% for coronary heart disease (Feng J He \& Macgregor, 2003).

However, the coastal community took fish and other seafoods, and also vegetable as daily consumption, it can help lowering the cardiovascular diseases risk. Result from previous study stated that physiological measures and prospective cohorts of disease outcomes together provide strong evidence that fruit and vegetable consumption lowers cardiovascular. Fish consumption is associated with lower incidence of CHD and ischemic stroke, especially risk of cardiac death, among generally healthy populations (Sofi \& Rodica, 2016). Potential differences in health effects depending on how the vegetables and seafood are cooked that require further investigation.

These risk factors that could lead premature degenerative diseases. If it is not immediately prevented can reduce productivity and have an impact on decreasing fishermen's income. Since most of coastal community only had 1 job, so, protect their health and prevent premature degenerative disease is important. Morover, based on meta-analysis study (Strazzullo et al., 2009), support for the role of reduction in salt intake for the prevention of cardiovascular disease should be continue and strengthen. Involving the fisherman's wife to maintain the husband health is proven effective (Espectato et al., 2017), since their natural mindset is prioritizing welfare and health of the family. 


\section{Conclusion}

The potential risks of degenerative diseases among the coastal community in Banyuwangi and Jember District were working outdoor with excessive sun exposure, smoking behaviour, cigarette smoke exposure, daily strenuous activity, unrestricted salt intake, and fatty food as the daily consumption. These potential risks can cause degenerative process of organs that could lead premature degenerative diseases. If it is not immediately prevented, it can reduce productivity and have an impact on decreasing fishermen's income. We recommend for strengthening the program that focus on monitoring the safety and environment for coastal community and supporting the reduction in salt intake for the prevention of cardiovascular disease.

\section{Declaration of Interest Statement}

The authors declare that they have no conflict of interests.

\section{Author Contribution}

AEN contributed to the development of study design, data analysis, and manuscript writing. AOM, SLD, MA, WYT, and SYP contributed to the data collection, data analysis, and manuscript writing. All authors commented on the manuscript and gave approval for the final version to be published.

\section{References}

Akmal, M., Kesani, A., Anand, B., Singh, A., Wiseman, M., \& Goodship, A. (2004). Effect of nicotine on spinal disc cells: a cellular mechanism for disc degeneration. Spine, 29, $568-575$.

American Lung Association. (2020). Tobacco Use Among Children and Teens. Lung.Org. https://www.lung.org/quit-smoking/smoking-facts/tobacco-use-among-children

Amila, Evarina Sembiring, N. A. (2021). DETEKSI DINI DAN PENCEGAHAN PENYAKIT DEGENERATIF PADA MASYARAKAT WILAYAH MUTIARA HOME CARE. Jurnal Kreativitas Pengabdian Kepada Masyarakat (PKM), 4(1), 102112.

An, H. S., Silveri, C. P., Simpson, J. M., File, P., Simmons, C., Simeone, F. A., \& Balderston, R. A. (1994). Comparison of smoking habits between patients with surgically confirmed herniated lumbar and cervical disc disease and controls. Journal of Spinal Disorders, 7(5), 369-373.

Armstrong, B. K., Philippe, A., Bajdik, C. D., Briss, P., Carter, R., Gruijl, F. R., Diffey, B. L., Dobbinson, S., Gallagher, R. P., Gies, P., Glanz, K., Lee, T. K., Ley, R. D., Neale, R., Reeve, V. E., Roy, C., Saraiya, M., Severi, G., Slaper, H., ... Whiteman, D. (2004). Prevention of Skin Cancer (D. Hill, J. M. Elwood, \& D. R. English (eds.); 3rd ed.). SPRINGER-SCIENCE+BUSINESS MEDIA, B.V.

Battié, M. C., Videman, T., Gill, K., Moneta, G. B., Nyman, R., Kaprio, J., \& Koskenvuo, M. (1991). 1991 Volvo Award in clinical sciences. Smoking and lumbar intervertebral disc degeneration: an MRI study of identical twins. Spine, 16(9), 1015-1021.

Boubriak, O. A., Watson, N., Sivan, S. S., Stubbens, N., \& Urban, J. P. (2013). Factors regulating viable cell density in the intervertebral disc: blood supply in relation to disc height. Journal of Anatomy, 222(3), 341-348. https://doi.org/10.1111/joa.12022

Central Bureau of Statistics of Jember. (2020). JEMBER DALAM ANGKA 2020. Badan Pusat Statistik Kabupaten Jember. 
Fogelholm, R. R., \& Alho, A. V. (2001). Smoking and intervertebral disc degeneration. Medical Hypotheses, 56(4), 537-539.

Handajani, A., Roosihermiatie, B., \& Maryani, H. (2012). Faktor-Faktor Yang Berhubungan Dengan Pola Kematian Pada Penyakit Degeneratif Di Indonesia. Buletin Penelitian Sistem Kesehatan, 13(1), 42-53. https://doi.org/10.22435/bpsk.v13i1Jan.2755

Hanum, G. R., \& Ardiansyah, S. (2018). Deteksi Dini Penyakit Degeneratif Pada Remaja Anggota Karang Taruna. Jurnal Abadimas Adi Buana, 2(1), 1-3. https://doi.org/10.36456/abadimas.v2.i1.a1615

He, F. J., \& MacGregor, G. A. (2002). Effect of modest salt reduction on blood pressure: a meta-analysis of randomized trials. Implications for public health. Journal of Human Hypertension, 16(11), 761-770. https://doi.org/10.1038/sj.jhh.1001459

He, F. J., \& MacGregor, G. A. (2009). A comprehensive review on salt and health and current experience of worldwide salt reduction programmes. Journal of Human Hypertension, 23(6), 363-384.

He, Feng J, \& Macgregor, G. A. (2003). How Far Should Salt Intake Be Reduced? Hypertension, 42(6),

1093-1099. https://doi.org/10.1161/01.HYP.0000102864.05174.E8

Indonesian Ministry of Health. (2016). Perilaku Merokok Masyarakat Indonesia (Berdasarkan Riskesdas 2007 dan 2013). https://pusdatin.kemkes.go.id/resources/download/pusdatin/infodatin/infodatin-haritanpa-tembakau-sedunia.pdf

Institute for Quality and Efficiency in Health Care. (2018). How much sun is too much? Https://Www.Ncbi.Nlm.Nih.Gov/. https://www.ncbi.nlm.nih.gov/books/NBK321117/

Iwahashi, M., Matsuzaki, H., Tokuhashi, Y., Wakabayashi, K., \& Uematsu, Y. (2002). Mechanism of intervertebral disc degeneration caused by nicotine in rabbits to explicate intervertebral disc disorders caused by smoking. Spine, 27(13), 1396-1401. https://doi.org/10.1097/00007632-200207010-00005

Jakoi, A. M., Pannu, G., D’Oro, A., Buser, Z., Pham, M. H., Patel, N. N., Hsieh, P. C., Liu, J. C., Acosta, F. L., Hah, R., \& Wang, J. C. (2017). The clinical correlations between diabetes, cigarette smoking and obesity on intervertebral degenerative disc disease of the lumbar spine. Asian Spine Journal, 11(3), 337-347. https://doi.org/10.4184/asj.2017.11.3.337

Jarvis, M. J., Tunstall-Pedoe, H., Feyerabend, C., Vesey, C., \& Saloojee, Y. (1987). Comparison of tests used to distinguish smokers from nonsmokers. American Journal of Public Health, 77(11), 1435-1438. https://doi.org/10.2105/ajph.77.11.1435

Kemenkes RI. (2019). Hasil Riset Kesehatan Dasar Tahun 2018. Kementrian Kesehatan RI, 53(9), 1689-1699.

Leboeuf-yde, C., Kjær, P., Bendix, T., \& Manniche, C. (2008). Self-reported hard physical work combined with heavy smoking or overweight may result in so-called Modic changes. BioMed Central, 11, 1-11. https://doi.org/10.1186/1471-2474-9-5

Liu, Y. J., Huang, G. S., Juan, C. J., Yao, M. S., Ho, W. P., \& Chan, W. P. (2009). Intervertebral disk degeneration related to reduced vertebral marrow perfusion at dynamic contrast-enhanced MRI. American Journal of Roentgenology, 192(4), 974979. https://doi.org/10.2214/AJR.08.1597

Livshits, G., Cohen, Z., Higla, O., \& Yakovenko, K. (2001). Familial history, age and smoking are important risk factors for disc degeneration disease in Arabic pedigrees. European Journal of Epidemiology, 17(7), 643-651. https://doi.org/10.1023/a:1015503329989 
Lohse, T., Rohrmann, S., Bopp, M., \& Faeh, D. (2016). Heavy Smoking Is More Strongly Associated with General Unhealthy Lifestyle than Obesity and Underweight. PLoS ONE, 11(2), 1-13. https://doi.org/10.1371/journal.pone.0148563

Mattila, V. M., Saarni, L., Parkkari, J., Koivusilta, L., \& Rimpelä, A. (2008). Early risk factors for lumbar discectomy: an 11-year follow-up of 57,408 adolescents. European Spine Journal: Official Publication of the European Spine Society, the European Spinal Deformity Society, and the European Section of the Cervical Spine Research Society, 17(10), 1317-1323. https://doi.org/10.1007/s00586-008-0738-2

Musdalifah, Indriastuti, D., \& Syahwal, M. (2020). Budaya Makan Masyarakat Pesisir Yang Beresiko Terjadi Hipertensi Pada Lansia Dini Di Kabupaten Konawe. Jurnal Keperawatan, 04(2), 1-8.

Neale, R. E., Davis, M., Pandeya, N., Whiteman, D. C., Green, A. C., \& Hill, S. (2007). Basal cell carcinoma on the trunk is associated with excessive sun exposure. In Journal of the American Academy of Dermatology (Vol. 56, Issue 3). https://doi.org/10.1016/j.jaad.2006.08.039

Rietbrock, N., Kunkel, S., Wörner, W., \& Eyer, P. (1992). Oxygen-dissociation kinetics in the blood of smokers and non-smokers: interaction between oxygen and carbon monoxide at the hemoglobin molecule. Naunyn-Schmiedeberg's Archives of Pharmacology, 345, 123-128.

Scientific Advisory Committee on Nutrition. (2003). Salt and Health.

Sofi, F., \& Rodica, M. (2016). Nutrition and prevention of chronic-degenerative diseases. Agriculture and Agricultural Science Procedia, 8, 713-717. https://doi.org/10.1016/j.aaspro.2016.02.052

Strazzullo, P., D’Elia, L., \& Cappuccio, F. P. (2009). Salt intake, stroke, and cardiovascular disease: meta- analysis of prospective studies. BMJ, 339(b4567), 1-9. https://doi.org/10.1136/bmj.b4567

Sun, Y., Liu, B., Snetselaar, L. G., Robinson, J. G., Wallace, R. B., Peterson, L. L., \& Bao, W. (2019). Association of fried food consumption with all cause, cardiovascular, and cancer mortality: prospective cohort study. BMJ, 364, k5420. https://doi.org/10.1136/bmj.k5420

Sundari, R., Widjaya, D. S., \& Nugraha, A. (2015). Lama Merokok dan Jumlah Konsumsi Rokok terhadap Trombosit pada Laki-laki Perokok Aktif. Kesmas: National Public Health Journal, 9(3), 257. https://doi.org/10.21109/kesmas.v9i3.692

The American Lung Association Epidemiology and Statistics. (2014). Substance Abuse and Mental Health Services Administration: National Survey on Drug Use and Health.

WHO. (2003). Radiation: Sun protection. World Health Organization, September. https://www.who.int/news-room/q-a-detail/radiation-sun-protection

World Health Organization. (2006). Reducing salt intake in populations : report of a WHO forum and technical meeting. 